\title{
The Social Networks of Adolescent Victims of Domestic Violence and Bullying
}

\author{
Grazielli Fernandes ${ }^{1}$ \\ Maria Angela Mattar Yunes ${ }^{2}$ (B) \\ Lirene Finkler ${ }^{3}$
}

\begin{abstract}
Domestic violence and bullying are public health problems with serious and lasting physical and emotional consequences. This study investigated the perception of the social and affective support network (characterized by the links between the family and school contexts) of adolescents victimized by domestic violence and involved in bullying. Fifteen student participants from a school in the south of Brazil answered to the Five Field Map. Participants were selected using a questionnaire on bullying and a question from the Questionário Juventude Brasileira [Brazilian Youth Questionnaire]. After analyzing the network's structure and adolescents' perceptions regarding significant people, results indicated a greater number of positive contacts in the Relatives, Family, and School fields. The most cited support figures were family, friends, and teacher. Adolescents indicated their perpetrators of domestic violence as positive contacts. Understanding significant relationships that predispose adolescents to involvement in bullying contributes to the implementation of appropriate interventions to prevent different expressions of violence.
\end{abstract}

Keywords: human development, family violence, bullying, adolescents

\section{A Rede de Apoio de Adolescentes Vítimas de Violência Doméstica e Bullying}

Resumo: Violência doméstica e bullying são problemas de saúde pública com sérias e duradouras consequências físicas e emocionais Este estudo investigou a percepção sobre a rede de apoio social e afetiva, caracterizada pelos vínculos entre os contextos familiar e escolar, de adolescentes vitimizados por violência doméstica e envolvidos em bullying. Participaram 15 estudantes de uma escola do Sul do Brasil, que responderam ao Mapa dos Cinco Campos. Os participantes foram selecionados por meio do Questionário sobre bullying e de uma questão do Questionário Juventude Brasileira. Analisadas estrutura e percepção de pessoas significativas, os resultados indicaram maior número de contatos positivos nos campos parentes, família e escola. As figuras de apoio mais citadas foram familiares, amigos e professor. Adolescentes indicaram seus perpetradores de violência doméstica como contatos positivos. Compreender relações significativas que predispõem adolescentes ao envolvimento em bullying contribui para a implementação de intervenções adequadas à prevenção de diferentes expressões de violência.

Palavras-chave: desenvolvimento humano, violência na família, bullying, adolescentes

\section{Las Redes de Apoyo de Adolescentes Víctimas de Violencia Doméstica y el Acoso}

Resumen: La violencia doméstica y el acoso son problemas de salud pública con consecuencias físicas y emocionales graves y duraderas. Este estudio investigó la percepción de la red de apoyo social y afectiva (caracterizada por los vínculos entre los contextos familiar y escolar) de los adolescentes víctimas de violencia doméstica e involucrados en el acoso escolar. Quince estudiantes participantes de una escuela en el sur de Brasil respondieron al Mapa de Cinco Campos. Los participantes fueron seleccionados mediante un cuestionario sobre acoso escolar y una pregunta del Questionário Juventude Brasileira [Cuestionario de la Juventud Brasileña]. Después de analizar la estructura de la red y las percepciones de los adolescentes con respecto a las personas significativas, los resultados indicaron un mayor número de contactos positivos en los campos de Familiares, Familia y Escuela. Las figuras de apoyo más citadas fueron familiares, amigos y maestros. Los adolescentes indicaron a sus autores de violencia doméstica como contactos positivos. Comprender las relaciones significativas que predisponen a los adolescentes a involucrarse en el acoso escolar contribuye a la implementación de intervenciones apropiadas para prevenir diferentes expresiones de violencia.

Palabras clave: desarrollo humano, violencia doméstica, bullying, adolescentes

\footnotetext{
${ }^{1}$ Universidade La Salle, Canoas-RS, Brazil

${ }^{2}$ Universidade Salgado de Oliveira, Niterói-RJ, Brazil

${ }^{3}$ Fundação de Assistência Social e Cidadania, Porto Alegre-RS, Brazil

Article derived from the Master's dissertation of the first author under the supervision of the second, defended in 2016, in the Graduate Program in Education at Universidade La Salle.

Correspondence address: Grazielli Fernandes. Universidade La Salle. Av. Victor Barreto, 2288, Canoas-RS, Brazil. CEP 92.010-000. E-mail: graziellifernandes@gmail.com
}

The power of different contexts to promote healthy human development has its theoretical basis on Bronfenbrenner's bioecological model $(1979 / 1996,2011)$. According to this theory, the environments are defined as microsystems or systems where face-to-face relationships and proximal activities/ roles with significant others are developed to form a number of mesosystems and exosystems. The latter refers to contexts where the person does not participate directly, 
such as for most children, the workplaces of their parents/ guardians and its impact on the family life. Involving all the above-mentioned contexts there are the macrosystems referring to values, beliefs systems, ideologies, patterns and lifestyles of a given social and cultural world.

Under this conceptual scope, the relevance of the family environment as the first setting for human development is undeniable. It is a relational system in which children meet their first "significant others," with whom they learn to exist within their cultural and social world. In the contemporary world, children establish extra-familial bonds at an early age. This takes place by means of ecological transitions, leading them to circulate in different educational spaces that generate multiple social roles. The school and day care center become important relational places for everyone to coexist, including the family. Ideally, this mesosystemic interaction between the family and the school should be horizontal, citizen-forming and protective (Brandão Neto et al., 2014). A syntonic system of family and school relations is defined by presenting people who live in both contexts with similar languages and socio-educational practices, common symbols, senses and meanings. For example, both family members and education professionals transmit close worldviews to children and adolescents, whose learning goes beyond formalist and content-bound knowledge. Harmony between these two contexts produces specific care, nurturing curiosities and emotions (Bronfenbrenner, 1979/1996, 2011). Intersubjective exchanges, meanwhile, acquire meanings built by experiences of positive affection and proximal processes of healthy development. Depending on its dynamics, this important social network can reinforce one's sense of belonging, strengthen personal image, promote a sense of self-efficacy and protect individuals from adverse situations, leading to the development of adaptation skills and quality relationships (Brito \& Koller, 1999).

Paradoxically, however, it is also in the day care, school and family environments that children and adolescents may be exposed to a variety of risk conditions. These situations - sometimes caused deliberately by close relations of the children - may lead them to end up in foster homes, potentially exposing them to risk elements, depending on the conditions of these institutions (Juliano \& Yunes, 2014). Other examples of psychosocial risk factors in proximal environments are often associated in domestic violence and bullying. These are harmful phenomena that by themselves are capable of hampering individuals' well-being, their physical and psychological integrity, freedom, and might threaten their fundamental rights to healthy development (Andrade et al., 2012; Smith, 2014).

Domestic violence is comprised of different forms of aggression perpetrated inside or outside the home by a family member or other people who have a parental role (even if they do not have blood ties) (Azevedo \& Guerra, 2011). In this work, modalities of bullying and violence are defined as follows: physical violence (use of physical force intentionally, not accidentally, in order to injure, damage or destroy, irrespective of evident marks); psychological violence (negative adult interference over the child and their social competence, depreciation, insults, exposure to ridicule, threats and intimidation, discrimination, rejection, omission of affection, denial of attention and supervision, and other non-physical forms of hostile treatment); sexual violence (any sexual act or game, homosexual or heterosexual relationship, between one or more adults - blood or affinity relatives and/ or guardians - and a child or adolescent); fatal violence (acts and/or omissions against the child or adolescent by parents, relatives or guardians that result in their death); negligence (failure to comply with health care recommendations; failure to seek appropriate health care; deprivation of food resulting in hunger; failure to provide physical development to the child; exposure of the child to drugs; inadequate protection from environmental dangers; abandonment; poor hygiene; being deprived of schooling).

Generally occurring in an educational environment, bullying is another type of risk-generating violence. This process occurs when a student is victimized or assaulted repeatedly, intentionally and without apparent motivation, by one or more aggressors. This assault is characterized by an explicit inequality of power between target(s) and perpetrator(s) (Olweus, 1993; Smith, 2014). Those involved in bullying can also play different roles: the passive victim is exposed to the negative and repetitive actions perpetrated by a person or a group but is unable to defend her/himself (Olweus, 1993); the aggressor victim reproduces ill-treatment they have suffered on someone more fragile (Olweus, 1993); the aggressor victimizes the weakest and feels an imperative need to dominate his/her peers (Olweus, 1993); the bystander does not participate directly in the aggression, but can act alongside the perpetrator by means of encouragement (inciting, helping, reinforcing) or discouragement (defending the victim) (Sentse, Veenstra, Kiuru, \& Salmivalli, 2014).

Any and all forms of violence can result in trauma to the extent that physical, emotional and social damages are found in the people involved. Some authors claim that victims of domestic violence are more prone to depression, anxiety and drug use (Yi et al., 2013); difficulties in relating emotionally with other people (Yi et al., 2013), and low school performance (Pieterse, 2015; Yi et al., 2013). A study by Taillieu, Brownridge, Sareen and Afifi (2016) assessed the impacts of psychological violence on the mental health of 34,653 American adults. These data demonstrated that having experienced this type of violence in childhood and adolescence increases the long-term risk of acquiring disorders such as mood swings, anxiety and substance abuse, as well as personality disorders, distrust in relation to others, apathy and distance from social relations.

Depending on the degree and intensity of the phenomenon, victims of bullying are also affected by mental and physical health disorders such as sadness, loneliness and suicidal ideation (Barzilay et al., 2017; Silva et al., 2018; Turner, Exum, Brame, \& Holt, 2013), low school performance (Pieterse, 2015; Silva et al., 2018; Yi et al., 2013), among other consequences. In extreme cases, victims can commit homicide or suicide (Smith, 2014). Aggressors, 
on the other hand, are more likely to engage in delinquent acts and become criminals (Copeland, Wolke, Angold, \& Costello, 2013), in addition to using tobacco, drugs and alcohol (Mello et al., 2017). As an example, a study with 1,874 North American adolescents by Turner et al. (2013) showed that the experience of any type of victimization by way of physical-, verbal-, or cyber-bullying was related to significantly higher depression scores for both boys and girls.

In many cases, these two experiences of violence are associated in someone's life and form a new and complex phenomenon. Thus, whether playing the role of victim or perpetrator, a child or adolescent may be victimized both at home and school - his two primary developmental environments and social sources of "protection." Two studies exemplify this tendency. A study by Brazilian researchers (Mello et al., 2017), based on the 2015 National School Health Survey, revealed that adolescents who reported being beaten by family members practiced more bullying as compared to those who had not suffered this type of violence. In the North American scenario, a study with 112 children and adolescents by Bauer et al. (2006) pointed out that $97 \%$ of bullying perpetrators have already been exposed to domestic violence.

Victims of domestic violence and bullying can suffer physical and psychological damage of different intensities, as noted in the literature. For this reason, it is important for them to be able to rely on a social, affective and political support network. Researchers claim that an effective network formed by people who make up a fabric of positive influences is capable of modifying, improving or altering personal and group responses to psychosocial risks (Juliano \& Yunes, 2014). A social network of positive and supportive relationships can neutralize the threats to development arising from multiple forms of violence, constituting a powerful protection node. This allows individuals to face, overcome and transmute difficult conditions, expressing resilience and the consequent personal or colective strengthening and transformation (Yunes, 2015).

Based on these reflections, this study aims to investigate how adolescent victims of domestic violence with involvement in bullying perceive their social and affective support network, characterized by the links between the family and school contexts. Thus, it will be possible to understand whether bonds developed by the participants in the family and school environments contribute to overcome violence. Furthermore, we argue that knowledge of social and support networks for victims of domestic violence and bullying is instrumental for supporting the development of educational projects that aim to prevent these forms of violence through protective mechanisms.

\section{Method}

\section{Participants}

Selected participants were fifteen (10 females and five males) students from a single municipal public school in southern Brazil, aged between 12 and 17 years, from the sixth to the ninth year of elementary education. The 15 adolescents were selected from a previous study, in which 112 participants answered to two instruments: the Questionário sobre bullying [Questionnaire on bullying] (Bandeira \& Hutz, 2012) and the Questionário Juventude Brasileira [Brazilian Youth Questionnaire] (Dell'Aglio, Koller, Cerqueira-Santos, \& Colaço, 2011).

Regarding forms of domestic violence, male adolescents reported that they suffered physical violence, psychological violence, and negligence. Female adolescents also suffered these same forms of violence. Besides, four reported having experienced sexual violence by aggressors who were relatives: uncles (three cases) or cousin (one case).

With regards to bullying in the male group, one declared himself as a perpetrator of bullying; one as a victim; three as victims/perpetrators; in the female group, two declared themselves as perpetrators; five as victims; three as victims/ perpetrators.

\section{Instruments}

Structured questionnaires. Questionário sobre bullying (Bandeira \& Hutz, 2012), which assessed bullying-related roles (victim, aggressor, victim/aggressor); Questionário Juventude Brasileira (Dell'Aglio et al., 2011), which assessed the experience of domestic violence.

Five Field Map. A quantitative and qualitative instrument for analyzing the characteristics of the support networks of children, adolescents and adults in terms of structure (quantity) and function (quality) of the established links (Siqueira, Tubino, Schwarz, \& Dell'Aglio, 2009). The Map consists of a felt board, to which symbolic 'chips' of different sizes (children, adolescents and adults of both sexes) representing the people who make up each field of the social and affective support network - are affixed. The map has five concentric circles, equally spaced and divided into pizza slices. Each field corresponds to a support network: family, school, relatives, friends/neighbor, and formal contacts. Each circle (or level) is used to measure the quality of the bond with the adolescent: the central circle represents the adolescent; the first and the second, their closest relations (stronger bonds); the third and fourth, their most distant relations (weaker bonds); the fifth, their unsatisfactory contacts. The obtained data and the researcher's findings are noted on a Registration Sheet (Siqueira et al., 2009).

\section{Procedure}

Data collection. This took place in two stages: in the first stage, the Questionnaire on bullying (Bandeira \& Hutz, 2012) and the Brazilian Youth Questionnaire (Dell'Aglio et al., 2011) were applied in the classroom with all participants, who were positioned so as to maintain individual privacy. Each session lasted approximately 40 minutes. The following steps were followed: (1) the researcher gave participants the questionnaire on bullying and read the procedures; (2) participants responded 
to the instrument; (3) the researcher delivered the Brazilian Youth Questionnaire (questions that evaluate domestic violence) and read the procedures; (4) participants responded to the instrument. At the end, all questionnaires were collected. The same researcher applied all instruments.

The second stage involved the application of the Five Field Map, which took place in individual sessions of approximately 30 minutes, on the premises of the school. Sessions for the application of the Five Field Map followed procedures indicated in the literature (Siqueira et al., 2009). The following steps were performed in each of the fields (family, school, relatives, friends/neighbor, formal contacts): presentation of the felt board, explanation of how the Map works, and beginning of the procedure, with the adolescent choosing a field, selecting one chip at a time, and putting it in the chosen circle. In accordance with defined procedures, they were asked who each chip represented: "Who is each person represented here?" and the order of choice was recorded on the Registration Sheet; participants were then asked whether there were conflicts $(†)$ - "Have you ever fought or argued with that person?" - or breakups (\#) - "Have you ever broke apart from her, i.e. stopped talking?" - in their relationships with each represented person. The information was then recorded in the Sheet. The subject may address conflicts and disruptions without being asked; in this case, no repeat question is asked; the subject is asked whether she/he likes coexisting with the represented person (Satisfaction/Dissatisfaction): "Do you like being with this person?". The information is recorded in the Sheet. The final Five Field Map procedure is to point out to the participant that he has countless people in her/his life and ask two questions: "Of all these people, who is the person you can count on most?" and "Why do you think you can count on her, what kind of support/help does she give you?"

Data analysis. Analysis of the Questionnaire on bullying (Bandeira \& Hutz, 2012) and of the Brazilian Youth Questionnaire's bullying question (Dell'Aglio et al., 2011): selected for the second stage were all participants who concomitantly declared themselves as victims of domestic violence and as perpetrators and/or victims of bullying. This justifies the difference in participation between the sexes.

Analysis of the Five Field Map carried out according to the following aspects (or dimensions): network structure (number of contacts, per field and total; number of people mentioned at each level); perception about the network's figures (quality of the relationship with the figures, according to the type of support they provided). For the analysis of the network structure, the total number and the average are presented. The categories of analysis developed by Siqueira et al. (2009) were used to describe the different types of support. These are: (1) Emotional/Affective Support: responses to affection and protection; (2) Informational Support: responses to receiving suggestions; advice, information and desired explanations that help the person feel oriented and (3) Instrumental Support: responses to the provision of some kind of material help or to receiving means for resolving daily problems.

\section{Ethical Considerations}

This study is part of a research that has been approved by the university's Ethics Committee (Process no. 43694215.2.0000.5307), certifying that all recommended standards were followed. It was also carried out in accordance with the rules of Resolution No. 466, December 12, 2012, of the National Health Council (Ministry of Health, 2012). All adolescents signed informed consent forms.

\section{Results}

This article presents the results of all fields presented by the Map. However, it should be noted that the emphasis will be on the analysis of the three main environments of interest: Family, Relatives and School, contexts in which adolescents experience the two forms of violence addressed here (domestic violence and bullying) in an associated way.

Regarding network structure, results are presented regarding (a) number of contacts (per field and total) and (b) number of people referenced at each level. According to the Five Field Map, adolescents had a total of 297 contacts. Table 1 shows each individual's number of contacts and the average number of people per social dimension. The fields with the largest number of contacts were Relatives, with an average of 5.1; Family, with an average of 4.7; School, with an average of 4.5 .

Table 2 shows each individual's number of contacts, as well as averages for each Map level.

Table 1

People mentioned per social dimension

\begin{tabular}{|c|c|c|c|c|c|c|c|c|c|c|c|c|c|c|c|c|}
\hline \multicolumn{17}{|c|}{ Number of people mentioned per social dimension } \\
\hline $\begin{array}{l}\text { Participant } \\
\text { Field }\end{array}$ & $\mathrm{P} 1$ & $\mathrm{P} 2$ & P3 & P4 & P5 & P6 & P7 & P8 & P9 & P10 & P11 & P12 & P13 & P14 & P15 & $\bar{x}_{\mathrm{b}}$ \\
\hline Family & 2 & 6 & 3 & 4 & 3 & 5 & 8 & 5 & 3 & 8 & 4 & 4 & 7 & 4 & 4 & 4.7 \\
\hline Relatives & 3 & 5 & 4 & 5 & 3 & 4 & 15 & 7 & 2 & 5 & 3 & 1 & 10 & 3 & 6 & 5.1 \\
\hline School & 4 & 6 & 4 & 3 & 5 & 3 & 8 & 5 & 5 & 4 & 1 & 4 & 5 & 2 & 8 & 4.5 \\
\hline $\begin{array}{l}\text { Friends } \\
\text { Neighbors }\end{array}$ & 3 & 4 & 3 & 3 & 3 & 2 & 3 & 3 & 3 & 3 & 6 & 3 & 12 & 2 & 3 & 3.7 \\
\hline Formal contacts & $\mathrm{a}$ & 2 & 1 & $\mathrm{a}$ & 2 & $\mathrm{a}$ & 3 & 4 & 3 & $\mathrm{a}$ & $\mathrm{a}$ & $\mathrm{a}$ & 6 & $\mathrm{a}$ & 7 & 1.9 \\
\hline
\end{tabular}

Note. $\mathrm{P}=$ Participant; $\bar{x}=$ Averages. 
Table 2

Number of people cited at each level

\begin{tabular}{|c|c|c|c|c|c|}
\hline Field & & & & & \\
\hline & $1 \mathrm{st}$ & 2nd & $3 \mathrm{rd}$ & 4th & 5 th \\
\hline Family & 28 & 25 & 8 & 4 & 5 \\
\hline Relatives & 35 & 23 & 5 & 6 & 7 \\
\hline School & 23 & 18 & 8 & 8 & 10 \\
\hline Friends/neighbors & 23 & 18 & 7 & 4 & 4 \\
\hline Formal contacts & 6 & 16 & 6 & $\mathrm{a}$ & $\mathrm{a}$ \\
\hline Averages & 23 & 20 & 6.8 & 4.4 & 5.2 \\
\hline
\end{tabular}

The highest averages appeared at the instrument's first and second levels, indicating that adolescents' relationship networks were more often positive than negative, even if they declared themselves victims of domestic violence and perpetrators and/or targets of bullying. Even so, it is noteworthy that the average of contacts at the fifth level was higher than at the fourth level.

To analyze their perception regarding network contacts, after completing the application of the Map, each adolescent was asked to answer two questions: (1) "Among the people you referred to on the Map, who is the one you can count on the most?"; (2) "What kind of support does that person give you?". Among the 15 respondents, six responded that their mother was the person they could count on most, followed by sister (three), friends/teenage sister-in-law (four), grandmother (one), father (one), and teacher (one).

Considering the categories used in the study by Siqueira et al. (2009), we found that the most cited type of support was Emotional/Affective Support, mentioned by 11 participants and identified in expressions such as: "tries to protect me," "helps me with everything," "is the only person who is on my side," "helps me when I fight with my mother," "supports me in everything," "takes care of me," "gives me love," "does everything for me." Informational Support was mentioned by four adolescents. Examples of responses are expressions such as "helps me with advice" and "is a good example for me." There was no mention of Instrumental Support.

\section{Discussion}

The use of the Five Field Map as an instrument of data collection allows for an in-depth assessment of the perceptions of individuals about their social support network. Moreover, it provides a framework for understanding elements of risk and protection in different contexts. This methodological strategy was fundamental to enable the comprehension of the interfaces between forms of violence experienced simultaneously in the school and family world, as well as their impacts.

Our first discussion topic refers to the number of people mentioned in each social dimension. The analysis of the network structure showed that contacts were concentrated in three main fields: Relatives, Family, and School. These three microsystems, knowingly important in the lives of children and adolescents, appeared with the same prominence in a study by Hoppe and Ramos (2012). It is not surprising that participants declare greater contact with people at these three levels, since they act as developmental environments for the establishment of activities, interactions, bonds and significant social roles (Bronfenbrenner, 1979/1996). Although many families are unaware of the impact of their internal relational networks on the lives of children and adolescents, it is undeniable that patterns within these social and emotional ties resonate in other ecological spaces. Upon entering the school world, children and adolescents experience new bonds of friendship and companionship, responsible for opening the social space beyond the home (Hoppe \& Ramos, 2012). When taking place in an ecological and integrative manner, this transition may result in a safe and welcoming network of relationships. Such mesosystemic connections are extremely important and can be protective or disruptive for the process of building identities, social skills, and subjective and collective well-being.

Regarding the family environment, adolescents reported more positive ties than negative ones, which is suggestive of a welcoming and protective network. However, a closer look at these links shows contradictory elements in some testimonies. Participants who experienced domestic violence - such as physical and psychological aggression or abandonment - cited their own aggressors as positive contacts. A teenager indicated her mother as a positive contact, even though she reported she had been physically and psychologically assaulted by her on the day the Map was applied (Registration Sheet). Therefore, positive contacts are not necessarily developmental tutors (Yunes, Fernandes, \& Weschenfelder, 2018). One of the reasons for this contradiction may be some adolescents' belief that certain violent practices, especially physical violence, are socially accepted and recognized as methods of education. These ideas become part of the moral system of the whole family, which affects the imagination of children and adolescents (Souza et al., 2015).

Moreover, it is important to note that the largest number of negative contacts from the entire social network was in the school space. Pointing that someone is in the 5th level of the Map may be a sign of potential risk factors. In this study, 5th-level contacts were perpetrators of bullying, as observed in the Registration Sheets. This information is relevant for educators, as it suggests that the child or adolescent is explicitly going through suffering and will need immediate, constant support and guidance. Therefore, it is 
necessary to build mechanisms that enable the educator to recognize risk situations, as it would be impractical to train educational professionals in applying methodological tools for diagnosing social networks, such as the Five Field Map. It is the school's duty to intervene in children's daily life and offer an environment of positive relationships - especially among peers, since these have undeniable affective and emotional efficacy (Yunes, 2015).

Although school life is routinely affected by bullying (often combined with violence experienced in the family sphere), some adolescents reported that they have positive relationships at school. These alleviate the stress caused by bullying and intra-family violence. This result strengthens the hypothesis that the two phenomena studied here have a great relational impact, and support between peers is an essential force for overcoming adversity. Despite many participants' perception that the school is a place of emotional insecurity and aggression, adolescents, whether victims or perpetrators, find their main links of affective support precisely in their peers. This occurs despite the fact that their colleagues are initially spectators of the bullying situation, and therefore part of the risk situation. However, only one participant reported receiving help from an adult member of the school microsystem. This piece of information is extremely relevant, as it points to adolescents' diminished reliance on educational agents (Giordani, Seffner, \& Dell'Aglio, 2017).

Thus, an important finding in this study is that peer support is an element of protection against the risk of bullying and family violence. Corroborating these ideas, a study that assessed the importance of peer support found that $72 \%$ participants stopped being victims of bullying two years later from the "turning point" of getting a best friend (Smith, Talamelli, Cowie, Naylor, \& Chauhan, 2004). This result is reiterated by researchers who develop actions to intervene against damages caused by bullying in schools. Thus, peer support is demonstrably one of the essential elements to overcome the traumas caused by bullying, as it helps strengthen self-esteem and acts as a protective factor (Yunes et al., 2018). The support of school colleagues can predispose individuals to face life's adverse and violent situations with greater psychic strength, both in the family and school environment.

As for work among families, it is important for them to be provided with guidance and invited to discuss codes and practices of educational and parental support. In this sense, Spanish researchers are developing strategies and programmatic models to support positive parenting in the school space (Rodríguez-Gutiérrez, Martín-Quintana, \& Cruz-Sosa, 2016). These may help dissipate the fragile notion of the school as a safe and welcoming place. By strengthening ties with its students and families, the school may obtain privileged opportunities to detect situations of domestic violence and diagnose their association with episodes of bullying. On this basis, it can act to prevent further negative developments, such as anxiety, drug use (Silva et al., 2018; Yi et al., 2013), low school performance (Pieterse, 2015; Silva et al., 2018; Yi et al., 2013) and other even more serious consequences, including depression and suicide (Silva et al., 2018; Smith, 2014).

In conclusion, it is important to highlight that this investigation has allowed us to identify a fundamental element of this issue, which needs to be considered seriously by researchers. Positive contacts with peers and the consciousness of education professionals can lead to a protective support social network. It is our belief that, if these adolescents feel welcomed and supported by their peer group and their educators, they can acquire confidence and motivation to disclosure their anxieties and overcome situations of violence in a transformative way, regardless of the context where they occur.

Therefore, by acquiring deeper knowledge about students' support social networks, the school obtains fundamental elements to start fighting against any form of systemic and overlapped ecological violence. The attention of school institutions to the evidence regarding violence at home or at school may contribute to overcoming adversity and activating resilience processes (Condorelli, 2015; Yunes et al., 2018). To do so, one must understand and transform the belief system of educators who deal with violence as if it was merely a composition of facts and isolated relational episodes resulting from indiscipline or 'normal' age-related problems (Lisboa, Horta, Weber, \& Almeida, 2014). An effective suggestion is to encourage active listening to reports of violence, so appropriate measures can be adopted to deal with each particular case.

Finally, we must reinforce the methodological limitations of this study, such as the low number of participants and the disproportion between boys and girls in the sample, making it unfeasible to carry out a gender-related analysis. We also believe that other members of the participants' social support network, such as family members or the school itself, should take part in new research in order to better understand the different perceptions. This study could also be carried out with adolescents who experience only domestic violence or bullying, as it may be that the variables discussed here are more strongly associated with one type of violence than the other. Despite these limitations, this study achieved its aims with a better understanding of adolescents' perceptions about their social support networks and a description of the structure and quality of their relational bonds.

It should be emphasized that it is the law and duty of all educational establishments to create measures to raise awareness, prevention, diagnose and combat violence and systematic intimidation, based on the implementation of Law No. 13,185 (2015), which institutes the Program to Combat Systematic Intimidation (Bullying) throughout the national territory. In addition, on May 14, 2018, the Federal Government signed Law No. 13,663, amending article 12 of the National Education Guidelines and Bases (Law 9.394/96), to "include the promotion of measures to raise awareness, prevent and combat all types of violence, and promote a culture of peace, among the tasks of educational establishments" (our translation). 
Therefore, schools have a social and civic obligation to develop intervention programs (Menesini \& Salmivalli, 2017) that encourage dialogue and the exercise of empathy, besides fostering relations of generosity and solidarity between peers, educators and families. To this end, they must jointly develop targeted and planned actions in the two microsystems that have the most decisive impact on the lives of children and adolescents: school and family (Bronfenbrenner, 1979/1996, 2011). Only then will a collective, effective support network emerge to aid in the daily struggle against all forms and expressions of domestic violence and bullying.

\section{References}

Andrade, S. S. C. A., Yokota, R. T. C., Bandeira de Sá, N. N., Silva, M. M. A., Araújo, W. N., Mascarenhas, M. D. M., \& Malta, D. C. (2012). Relação entre violência física, consumo de álcool e outras drogas e bullying entre adolescentes escolares brasileiros [Association between physical violence, consumption of alcohol and other drugs, and bullying among Brazilian adolescentes]. Cadernos de Saúde Pública, 28(9), 1725-1736. doi:10.1590/S0102-311X2012000900011

Azevedo, M. A., \& Guerra, V. N. A. (Orgs.). (2011). Infância $e$ violência doméstica: Fronteiras do conhecimento [Childhood and domestic violence: Frontiers of knowledge]. São Paulo, SP: Cortez.

Bandeira, C. M., \& Hutz, C. S. (2012). Bullying: Prevalência, implicações e diferenças entre os gêneros [Bullying: Prevalence, implications and gender differences]. Psicologia Escolar e Educacional, 16(1), 35-44. doi: 10.1590/S1413-85572012000100004

Barzilay, S., Brunstein Klomek, A., Apter, A., Wasserman, C., Hadlaczky, G., Hoven, C. W., ... Wasserman, D. (2017). Bullying victimization and suicide ideation and behavior among adolescents in Europe: A 10-country study. Journal of Adolescent Health, 61(2), 179-186. doi:10.1016/j.jadohealth.2017.02.002

Bauer, N. S., Herrenkohl, T. I., Lozano, P., Rivara, F. P., Hill, K. G., \& Hawkins, J. D. (2006). Childhood bullying involvement and exposure to intimate partner violence. Pediatrics, 118(2), e235-242. doi:10.1542/peds.2005-2509

Brandão Neto, W., Silva, A. R. S., Almeida Filho, A. J., Lima, L. S., Aquino, J. M., \& Monteiro, E. M. L. M. (2014). Educational intervention on violence with adolescents: Possibility for nursing in school context. Escola Anna Nery, 18(2), 195-201. doi:10.5935/1414-8145.20140028

Brito, R. C., \& Koller, S. H. (1999). Desenvolvimento humano e redes de apoio social e afetivo [Human development and social and affective support networks]. In A. M. Carvalho (Org.), O mundo social da criança: Natureza e cultura em ação [The social world of the child: Nature and culture in action] (pp. 115-126). São Paulo, SP: Casa do Psicólogo.
Bronfenbrenner, U. (1996). A ecologia do desenvolvimento humano: Experimentos naturais e planejados [The ecology of human development: Experiments, nature and design] (M. A. V. Veronese, Trans.). Porto Alegre, RS: Artes Médicas. (Original work published 1979)

Bronfenbrenner, U. (2011). Bioecologia do desenvolvimento humano: Tornando os seres humanos mais humanos [Bioecology of human development: Making human beings more human] (A. Carvalho-Barreto, Trans.). Porto Alegre, RS: Artmed.

Condorelli, A. (2015). O florescer do lótus na lama: Sobre educação e resiliência [The lotus bloom in the mud: About education and resilience]. In S. Cabral \& B. Cyrulnik (Orgs.), Resiliência: Como tirar leite de pedra [Resilience: How to get milk from stone] (pp. 121-135). São Paulo, SP: Casa do Psicólogo.

Copeland, W. E., Wolke, D., Angold, A., \& Costello, E. J. (2013). Adult psychiatric outcomes of bullying and being bullied by peers in childhood and adolescence. JAMA Psychiatry, 70(4), 419-426. doi:10.1001/ jamapsychiatry.2013.504

Dell'Aglio, D. D., Koller, S. H., Cerqueira-Santos, E., \& Colaço, V. F. R. (2011). Revisando o Questionário da Juventude Brasileira: Uma nova proposta [Reviewing the Brazilian Youth Questionnaire: A new proposal]. In D. D. Dell'Aglio \& S. H. Koller (Orgs.), Adolescência e juventude: Vulnerabilidade e contextos de proteção [Adolescence and youth: Vulnerability and protection contexts] (pp. 259-270). São Paulo, SP: Casa do Psicólogo.

Giordani, J. P., Seffner, F., \& Dell'Aglio, D. D. (2017). Violência escolar: Percepções de alunos e professores de uma escola pública [School violence: Perceptions of students and teachers of a public school]. Psicologia Escolare Educacional, 21(1), 103-111.doi:10.1590/21753539/2017/02111092

Hoppe, M., \& Ramos, K. M. (2012). Redes de apoio social e intersetorialidade entre educação e saúde nos anos iniciais do ensino fundamental [Social support networks and intersectoriality between education and health in the initial years of elementary education]. Revista Educação, Cultura e Sociedade, 2(2), 47-62. Retrieved from http:// sinop.unemat.br/projetos/revista/index.php/educacao/ article/view/1000/703

Juliano, M. C. C., \& Yunes, M. A. M. (2014). Reflections on the social support network as a mechanism for the protection and promotion of resilience. Ambiente \& Sociedade, 17(3), 135-154. doi:10.1590/S1414753X2014000300009

Lei No. 13.185, de 06 de novembro de 2015. (2015, 09 de novembro). Institui o Programa de Combate à Intimidação Sistemática (Bullying) [Establishes the program to combat systematic intimidation (Bullying)]. Diário Oficial da União, seção 1. 
Lei No. 13.663, de 14 de maio de 2018. (2018, 15 de maio). Altera o art. 12 da Lei $\mathrm{n}^{\circ} 9.394$, de 20 de dezembro de 1996, para incluir a promoção de medidas de conscientização, de prevenção e de combate a todos os tipos de violência e a promoção da cultura de paz entre as incumbências dos estabelecimentos de ensino [Changes the art. 12 of law 9.394 of december 20,1996, to include the promotion of measures to raise awareness, prevent and combat all types of violence, and promote a culture of peace among the responsibilities of educational institutions]. Diário Oficial da União, seção 1.

Lisboa, C. S. M., Horta, C. L., Weber, J. L. A., \& Almeida, L. (2014). Mitos e fatos sobre bullying [Myths and facts about bullying]. In C. S. M. Lisboa, G. W. Wendt, \& J. R. Pureza (Orgs.), Mitos \& fatos sobre bullying: Orientação a pais e profissionais [Myths \& facts about bullying: Counseling parents and professionals] (pp. 15-27). Novo Hamburgo, RS: Sinopsys.

Mello, F. C. M., Silva, J. L., Oliveira, W. A., Prado, R. R., Malta, D. C., \& Silva, M. A. I. (2017). The practice of bullying among Brazilian schoolchildren and associated factors, National School Health Survey 2015. Ciência \& Saúde Coletiva, 22(9), 2939-2948. doi:10.1590/141381232017229.12762017

Menesini, E., \& Salmivalli, C. (2017). Bullying in schools: The state of knowledge and effective interventions. Psychology, Health \& Medicine, 22(Suppl. 1), 240-253. doi:10.1080/13548506.2017.1279740

Ministério da Saúde. Conselho Nacional de Saúde. Resolução No. 466, de 12 de dezembro de 2012. (2012). Retrieved from http://bvsms.saude.gov.br/bvs/saudelegis/cns/2013/ res0466_12_12_2012.html

Olweus, D. (1993). Bullying at school: What we know and what we can do. Malden, MA: Blackwell.

Pieterse, D. (2015). Childhood maltreatment and educational outcomes: Evidence from South Africa. Health Economics, 24(7), 876-894. doi:10.1002/hec.3065

Rodríguez-Gutiérrez, E., Martín-Quintana, J. C., \& Cruz-Sosa, M. (2016). Living Adolescence in Family parenting program: Adaptation and implementation in social and school contexts. Psychosocial Intervention, 25(2), 103-110. doi:10.1016/j.psi.2016.03.004

Sentse, M., Veenstra, R., Kiuru, N., \& Salmivalli, C. (2014). A longitudinal multilevel study of individual characteristics and classroom norms in explaining bullying behaviors. Journal of Abnormal Child Psychology, 43(5), 943-955. doi:10.1007/s10802-014-9949-7

Silva, J. L., Mello, F. C. M., Oliveira, W. A., Prado, R. R., Silva, M. A. I., \& Malta, D. C. (2018). Bullying victimization among Brazilian students: Results of the National Survey of School Health (PENSE). Texto \& Contexto-Enfermagem, 27(3), e0310017. doi:1590/010407072018000310017
Siqueira, A. C., Tubino, C. L., Schwarz, C., \& Dell'Aglio, D. D. (2009). Percepção das figuras parentais na rede de apoio de crianças e adolescentes institucionalizados [Perception of parental figures in institutionalized children and adolescents' support network]. Arquivos Brasileiros de Psicologia, 61(1), 176-190. Retrieved from http://pepsic.bvsalud.org/scielo.php?script=sci_ arttext\&pid=S1809-52672009000100017

Smith, P. K. (2014). Understanding school bullying: Its nature \& prevention strategies. London, United Kingdom: Sage.

Smith, P. K., Talamelli, L., Cowie, H., Naylor, P., \& Chauhan, P. (2004). Profiles of non-victims, escaped victims, continuing victims, and new victims of school bullying. British Journal of Educational Psychology, 74(Pt. 4), 565-581. doi:10.1348/0007099042376427

Souza, S. H. R., Nakamura, E., Martin, D., Macedo, T. C., Bordin, I., \& Mari, J. J. (2015). A visão de pais e adolescentes de uma periferia de Santos, sobre violência física doméstica [The view of parents and adolescents from a periphery of Santos, about domestic physical violence]. Revista do Laboratório de Estudos da Violência e Segurança, (16), 119-136. Retrieved from http://www2.marilia.unesp.br/revistas/index.php/levs/ article/viewFile/5594/3842

Taillieu, T. L., Brownridge, D. A., Sareen, J., \& Afifi, T. O. (2016). Childhood emotional maltreatment and mental disorders: Results from a nationally representative adult sample from the United States. Child Abuse \& Neglect, 59, 1-12. doi:10.1016/j.chiabu.2016.07.005

Turner, M. G., Exum, L., Brame, R., \& Holt, T. J. (2013). Bullying victimization and adolescent mental health: General and typological effects across sex. Journal of Criminal Justice, 41(1), 53-59. doi:10.1016/j. jcrimjus.2012.12.005

Yi, S., Poudel, K. C., Yasuoka, J., Yi, S., Palmer, P. H., \& Jimba, M. (2013). Exposure to violence in relation to depressive symptoms among male and female adolescent students in Cambodia. Social Psychiatry and Psychiatric Epidemiology, 48(3), 397-405. doi:10.1007/s00127-012-0553-2

Yunes, M. A. M. (2015). Dimensões conceituais da resiliência e suas interfaces com risco e proteção [Conceptual dimensions of resilience and its interfaces with risk and protection]. In S. G. Murta, C. Leandro-França, K. B. Santos, \& L. Polejack (Orgs.), Prevenção e promoção em saúde mental: Fundamentos, planejamento e estratégias de intervenção [Prevention and promotion in mental health: Fundamentals, planning and intervention strategies] (pp. 93-112). Novo Hamburgo, RS: Sinopsys.

Yunes, M. A. M., Fernandes, G., \& Weschenfelder, G. V. (2018). Intervenções psicoeducacionais positivas para promoção de resiliência: O profissional da educação como tutor de desenvolvimento [Positive psychoeducational interventions to promote resilience: The educator as a developmental tutor]. Educação (Porto Alegre), 41(1), 83-92. doi:10.15448/1981-2582.2018.1.29766 
Grazielli Fernandes is a $\mathrm{PhD}$ candidate in Universidade $\mathrm{La}$ Salle, Canoas-RS, Brazil.

Maria Angela Mattar Yunes is a Professor of the Psycology Department of the Universidade Salgado de Oliveira, Niterói-RJ, Brazil.

Lirene Finkler is a Professor of the Fundação de Assistência Social e Cidadania, Porto Alegre-RS, Brazil.

Authors' contributions:

All authors made substantial contributions to the conception and design of this study, to data analysis and interpretation, to manuscript revision and to approval of the final version. All authors assume public responsibility for the contents of the manuscript.

Received: Feb. 01, 2018

1st Revision: Aug. 30, 2018

2nd Revision: Nov. 16, 2018

Approved: Nov. 30, 2018

How to cite this article:

Fernandes, G., Yunes, M. A. M., \& Finkler, L. (2020).

The social networks of adolescent victims of domestic violence and bullying. Paidéia (Ribeirão Preto), 30, e3007. doi:http://dx.doi.org/10.1590/1982-4327e3007 